\title{
THE OPEN SCHOOLHOUSE: ITS PART IN THE VACATION OF THE STAY-AT-HOME
}

\author{
FLORENCE K. GRISWOLD
}

Teachers College, Columbia University, New York City, N. Y.

Each year the Board of Education of New York City strives to make the school an actual part of the life, not only of the children but of their parents. The buildings are open for lectures for people of all ages on all subjects. Boys and girls now have their clubs in the same rooms in which they learned the three R's. All these things go on in the winter, but in the sunmer, during the long vacation, when the schoolhouse used to rest, the blinds are no longer down, but every day may be seen the same children of the winter, thronging to school because they want to go-for summer school is not compulsory.

These schools are real homes to both children and parents of the congested districts. Their first great purpose is to keep the children off the streets by furnishing them with pleasant and practical employment. But their work is of a more farreaching character than to teach actual trades. They aim to bring about a better understanding of what the good things in life are, and to help the children onward. In the summer school the discipline is very light, hence the teacher comes into closer contact with her little charges than in regular school. She knows more of their actual lives, of their thoughts and feelings, thus she has greater possibilities and can really be of more assistance in bringing about a better condition.

The open schoolhouse in the summer is divided into three different departments. There is first the summer school from nine to twelve in the morning in which the children are taught the manual arts principally. This is for children of all ages. In the afternoon from one until five o'clock, there is the playground. Here games are played, there is no work- "just fun." The gymnasium is open for the larger boys. While both of 
these are good and enjoyed by the children, it is the evening that both parent and child alike look forward to. At seventhirty the vari-colored electric bulbs on the roof of the schoolhouse begin to light and shed a soft radiance far out like that of a lighthouse; only its mission is different, for it bids the people to come, not to keep off. The tired people of the neighborhood watch for it; it means to them the school roof-garden is open. Soon the band begins to play and the people go trooping up for a waltz or a quiet chat with the neighbors. Until ten o'clock, an orderly throng come and go, waltz and promenade, talk and laugh. Then the school-building becomes quiet again, darkness reigns, but the rest is of short duration, for at eight o'clock in the morning the baths are open; the child not only may go to school in summer, but he may go clean, a luxury that is not always appreciated by the East-sider, although the baths have a large patronage.

In the morning the classes are given over to the practical needs of life, to which, in winter, lack of time prevents giving more than an hour or two a week. There are classes in elementary and advanced sewing, knitting, cooking, dressmaking, embroidery, millinery, and nursing for the girls; while the boys are taught carpentry, chair-caning, weaving, basketry, and bookbinding. The leather-tooling classes are generally very large; poor parents are practical, particularly the Jewish and Italian, who readily see what is good and free, and will help them "on" in life.

Boston was the first city to grasp the idea of keeping the schools open in summer. New York soon followed, and has so perfected the idea, that educators from other cities are now studying her schools as modeis. The latter city, after a severe financial struggle, has been able to keep open over thirty schoolhouses. These are in the congested districts all over Greater New York and are well equipped for teaching industrial subjects.

To illustrate what the open schoolhouse means to a certain class of children, the following story was told by one of the teachers: When twelve o'clock came, the hour for dismissal, one tiny child did not rise from her seat, but sat still looking dis- 
consolately around. When the teacher asked her why she did not go home, she looked at her and answered with a plaintive voice, "I ain't got no place to go; my mamma, she went out early this morning and locked up the room. Please teacher, can I stay here, the boys beat me on the street, and my mamma will not be home for a long time; not until dark." Only the teacher and the settlement worker know how many children are locked out from morning until night sometimes by worthless mothers, who go their own way, and leave the children to the mercy of anyone who will give them a few pennies, or a place of refuge from the cruelty of the children of the street, but mostly by parents who must leave their homes in order to provide bread to fill the always-hungry mouths. 